\title{
A Surprising Outcome of a Patient with Psychosis: Progressive Emphysema Associated with Pneumorrhachis
}

\author{
Psikozlu Hastada Şaşırtıcı Bir Sonuç: Pnömoraşi Illişkili Ilerleyici Amfizem
}

\author{
(D) Emine Polat1, (I) Halise Akça2, (I) Nilden Tuygun33, (D) Hasibe Gökçe Çınar4, (D) Can Demir Karacan² \\ ${ }^{1}$ Dr. Sami Ulus Maternity Child Health and Diseases Education and Research Hospital, Department of Child Health and Diseases, \\ Ankara, Turkey \\ ${ }^{2}$ Ankara Yıldırım Beyazıt University Faculty of Medicine, Department of Pediatric Emergency Medicine, Ankara, Turkey \\ ${ }^{3}$ Dr. Sami Ulus Maternity Child Health and Diseases Education and Research Hospital, Department of Pediatric Emergency Medicine, Ankara, Turkey \\ ${ }^{4}$ Dr. Sami Ulus Maternity Child Health and Diseases Education and Research Hospital, Department of Radiology, Ankara, Turkey
}

\section{Abstract}

Air can be detected in various anatomical regions during the course of several diseases. This accumulation of air is often seen as pneumothorax and subcutaneous emphysema. Rarely extraordinary regions such as skull base and spinal region can be involved. In the majority of the patients, it is caused by trauma, iatrogenic factors and Valsalva maneuver. Supportive treatment is generally sufficient. A 14-year-old boy with psychosis who developed extensive air in the scull base, the neck, the orbita, mediastinum, abdomen, retroperitoneum, spinal canal, scrotum and head of the femur was presented. In the course of psychiatric disorders, in the case of excessive shouting and self-harm as a result of squeezing the throat, beside subcutaneous emphysema, air existing in the various anatomical regions of the body should be kept in mind.

Keywords: Emphysema, pneumomediastinum, pneumorrhachis

\section{Öz}

Bazı hastalıkların seyri sırasında çeşitli anatomik bölgelerde hava tespit edilebilir. Bu hava birikimi çoğunlukla pnömotoraks ve cilt altı amfizemi şeklinde görülür. Nadiren kafa tabanı ve spinal kanal gibi sıra dışı alanlarda da olabilir. Hastaların büyük çoğunluğunda travma, iyatrojenik nedenler ve Valsalva manevrasına bağlı oluşmaktadır. Destek tedavi genellikle yeterlidir. Psikoz tanısıyla başvuran ve kafa tabanı, boyun, orbita, mediastinum, karın, retroperitoneal alan, spinal kanal, skrotum ve femur başında aşırı hava birikimi olan 14 yaşında bir hasta sunulmuştur. Psikiyatrik hastalıkların seyri sırasında aşırı bağırma ve boynu sıkma gibi kendine zarar verme hareketlerinin sonucu olarak deri altı amfizemin yanı sıra vücudun çeşitli anatomik bölgelerinde hava birikimi olabileceği akılda tutulmalıdır.

Anahtar Kelimeler: Amfizem, pnömomediastinum, pnömoraşi

\section{Introduction}

In childhood, bronchial asthma, vomiting and Valsalva maneuver are responsible for collection of free air in various anatomical regions. Subcutaneous emphysema, pneumothorax and pneumomediastinum generally occur in consequence of esophageal or bronchial ruptures due to trauma, iatrogenic factors, infections, coughing and severe vomiting. ${ }^{1-3}$ Pneumorrhachis is characterized by the presence of ectopic air in the spinal canal. It can be observed in the cases of trauma, epidural anesthesia, epidural abscess, lumbar puncture and pneumomediastinum. These disorders rarely develop spontaneously. ${ }^{3}$

Here, 14-years-old male adolescent with respiratory distress and subcutaneous emphysema spreading from scalp to scrotal region due to shouting and squeezing his throat was presented.

\section{Case Report}

A previously healthy 14-year-old male adolescent was brought by his parents to the Pediatric Emergency Department with

Address for Correspondence/Yazışma Adresi: Halise Akça MD, Ankara Yıldırım Beyazıt University Faculty of Medicine, Department of Pediatric Emergency Medicine, Ankara, Turkey

E-mail: haliseakca@gmail.com ORCID ID: orcid.org/0000-0003-4990-5735

Received/Geliş Tarihi: 24.01.2018 Accepted/Kabul Tarihi: 15.05.2018

${ }^{\circ}$ Copyright 2019 by Society of Pediatric Emergency and Intensive Care Medicine

Journal of Pediatric Emergency and Pediatric Intensive Care published by Galenos Yayınevi. 
progressive respiratory distress and severe headache for the last one week. On initial physical examination, he had a poor general condition with a Glasgow coma scale of 13 . The patient had tachypnea (38 breaths/minute), tachycardia (110 beats/minute) with no detectable blood pressure and oxygen saturation of $97 \%$. He also had poor peripheral circulation signs with prolonged capillary refill time (4 seconds). Heart and breath sounds were both faintly audible. Wide subcutaneous emphysema and crepitus extending scalp to inguinal region were determined. Other systemic examinations were normal. After maintaining airway, oxygen and intravenous boluses of normal saline fluid, the patient showed gradual recovery with a blood pressure of $92 / 64 \mathrm{mmHg}$. There was voltage suppression in electrocardiogram. Laboratory studies were normal except of respiratory alkalosis. Excessive air was detected in both chest and abdominal radiographs (Figure 1). Echocardiography and abdominal ultrasonography couldn't be performed due to presence of excessive air. Ectopic air in orbital cavities, servical spaces, mediastinum, epidural space, extraperitoneal abdomen and scrotum was depicted on computed tomography of head, neck, thorax and abdomen (Figure 2, 3). His parents reported that he had social isolation and cognitive decline for one year and experienced screaming and squeezing his throat for one month when he could not cope with psychological crisis. The parents denied any history of illicit drug abuse and trauma. He underwent elective tracheal intubation because of increasing respiratory distress. He was extubated after 5 days of mechanical ventilation in pediatric intensive care unit. Subcutaneous emphysema was

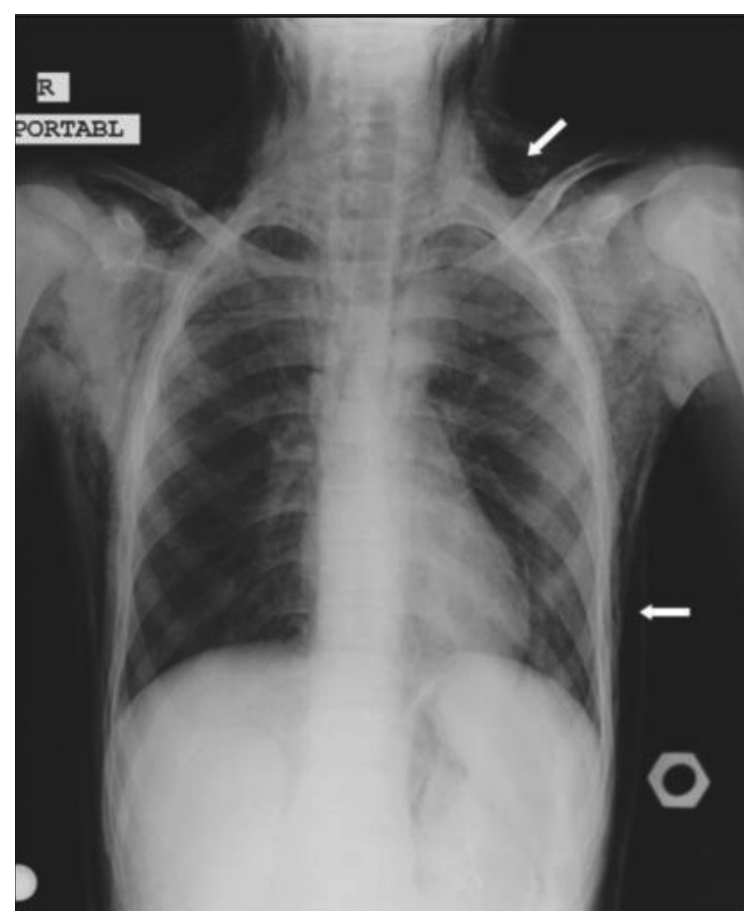

Figure 1. Posteroanterior chest graphy, subcutaneous emphysema gradually improved (Figure 4). On laryngoscope examination, the mucous membranes were intact. Agitation was observed when the patient was awake. Psychiatry department suggested Olanzapine and Chlorpromazine for the treatment of psychosis. No organic etiology such as encephalitis, tumor, trauma and poisoning was detected regarding to psychosis. The emergence of symptoms and signs of the patient were considered due to squeezing of his throat and his screaming during psychotic episodes.

\section{Discussion}

Children with no underlying diseases might also develop spontaneous pneumomediastinum. ${ }^{4.6}$ Pneumomediastinum may be seen due to alveolar wall ruptures during increased intrathoracic pressure. Diagnostic and therapeutic delay increases the risk of accumulation of massive air effusion and

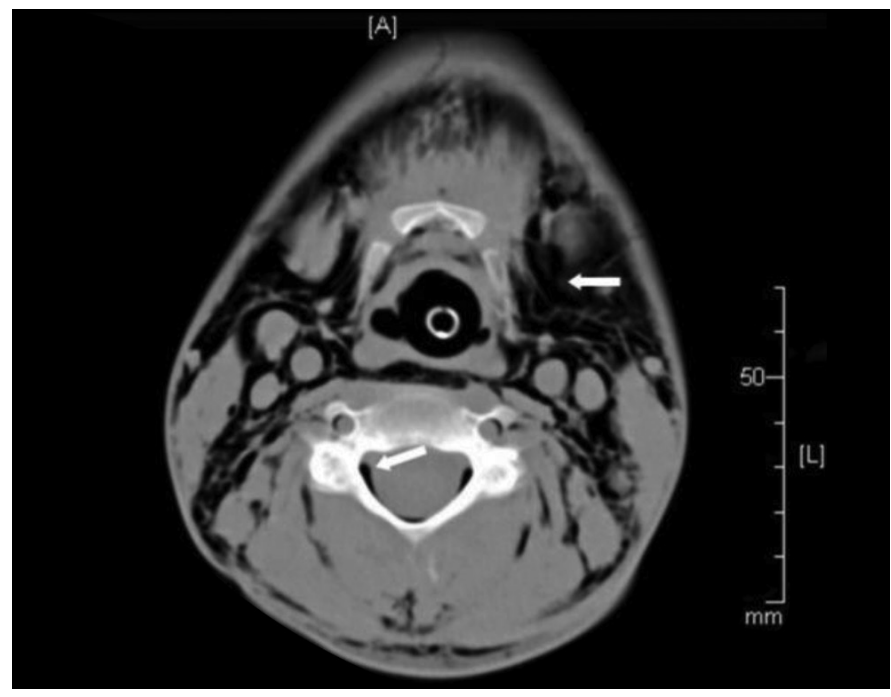

Figure 2. The presence of air in deep neck spaces, spinal canal in neck computed tomography

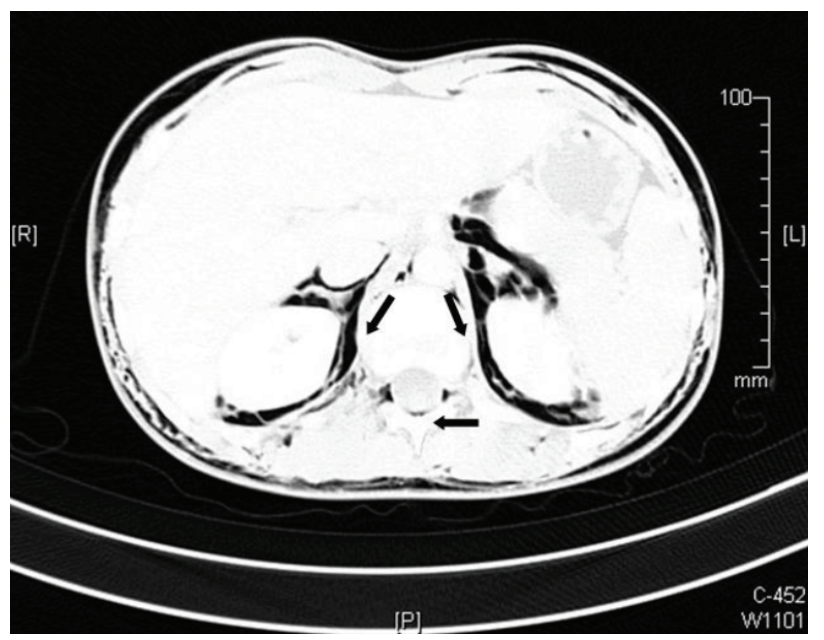

Figure 3. The presence of air in retroperitoneum and subcutaneous emphysema in abdominal computed tomography 
compression of vital structures of the neck and the chest. Therefore, cardiac output and blood pressure fall. ${ }^{2}$ Our patient had no hypotension during admission.

Belotti et al. reported a 14-years-old female who presented with chest pain that is complicated with spontaneous pneumomediastinum and pneumorrhachis. ${ }^{7}$ Pneumorrhachis can be seen in epidural anesthesia, epidural abscess, lumbar puncture, scalp or spinal injuries, and traumatic pneumothorax or pneumomediastinum. Rupture of peripheral pulmonary alveoli may be seen due to increased intrathoracic pressure. Thereafter, the air passes to mediastinum which is connected to retropharyngeal space and finally free air reaches to epidural space. ${ }^{8}$ There is no barrier between the posterior mediastinum or the retropharyngeal space and the epidural space. Free air accumulates in the epidural space by means of the neural foramina. There are very few reports of association of pneumomediastinum and pneumorrhachis with no thoracic injury in the published literature. ${ }^{3}$ Our patient had no risk factors, but we determined air extending from cervical to lumbar spinal canal by computed tomography. Besides pneumomediastinum and pneumorrhachis, extensive air was detected in the skull base, the orbita, abdomen, retroperitoneum, scrotum and femoral head. We couldn't explain these findings by mechanisms previously reported in the literature. We thought that, Valsalva maneuver resulting from severe and prolonged shouting and throat squeezing led to pneumomediastinum, thereafter existing air moved to adjacent anatomic areas.

Radiological features of pneumomediastinum seen on chest X-ray are caused by air outlining normal anatomic structures. Pneumorrhachis is often easily visible on a lateral chest radiograph, where the air appears as linear

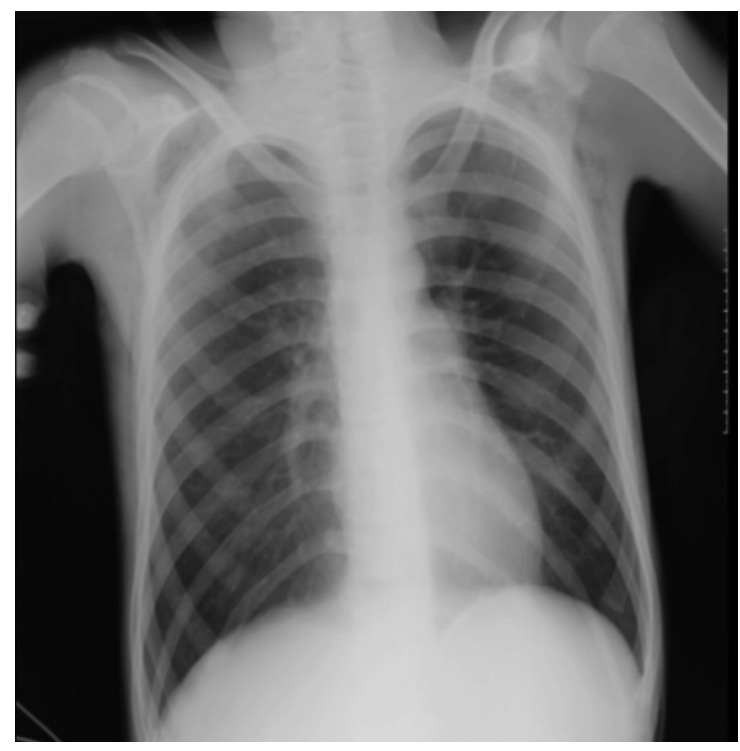

Figure 4. Normal posteroanterior chest graphy after treatment lucencies along the spinal canal. Computed tomography in the diagnosis of pneumorrhachis is considered a fast and reliable method. Since pneumorrhachis is often combined with air distribution in other parts of the body, observations suggest a common indication for the use of computed tomography, and if necessary, even a computed tomography or magnetic resonance imaging of the whole-body. There may be voltage suppression on the electrocardiogram. On follow-up, our patient's electrocardiography was normal and chest radiographs demonstrated resolution of the pneumomediastinum.

Supportive treatment with oxygen, analgesics, bed rest and clinical monitoring are sufficient in the management. The air usually resolves by itself without specific treatment.

Prognosis is generally good and depends on the amount of the air in the mediastinum and underlying etiological factors. If tension pneumothorax develops, the outcome will be fatal. 9,10 Our patient was mechanically ventilated in pediatric intensive care unit for five days. At the end of first week, there was a significant improvement in general condition of patient. Despite the complete recovery of respiratory distress, psychiatric problems persisted.

During the course of psychotic episodes, in case of excessive screaming and self-harm as a result of squeezing the throat, beside subcutaneous emphysema, the presence of air in various parts of the body should be kept in mind. To our knowledge, this is the first case reported with psychosisassociated extensive emphysema.

\section{Study Limitations}

We can't explain how the free air travels around femoral head and into scrotum.

\section{Ethics}

Ethics Committee Approval: N/A.

Informed Consent: We obtained informed consent from the child's parents.

Peer-review: Externally peer-reviewed.

\section{Authorship Contributions}

Surgical and Medical Practices: H.A., E.P., N.T., C.D.K., H.G.C., Concept: H.A., E.P., N.T., Design: H.A., N.T., Data Collection or Processing: H.A., N.T., H.G.C., Analysis or Interpretation: H.A., N.T., C.D.K., H.G.C., Literature Search: H.A., N.T., Writing: H.A., N.T.

Conflict of Interest: No conflict of interest was declared by the authors.

Financial Disclosure: The authors declared that this study has received no financial support. 


\section{References}

1. Colavita L, Cuppari C, Pizzino MR, Sturiale M, Mondello B, et al. Pneumomediastinum, subcutaneous emphysema and pneumorrhachis in asthmatic children. J Biol Regul Homeost Agents. 2016;30:585-8

2. Hmami $F$, Oulmaati $A$, Boubou $M$, Chakib Benjelloun $M$, Hida $M$, et al. Subcutaneous emphysema, pneumomediastinum, pneumopericardium, pneumorachis, and pneumoretroperitoneum revealing an unknown foreign body aspiration. Arch Pediatr. 2015;22:978-81.

3. Emiralioglu N, Ozcan HN, Oguz B, Yalcin E, Dogru D, et al. Pneumomediastinum, pneumorrhachis and subcutaneous emphysema associated with viral infections: Report of three cases. Pediatr Int. 2015;57:1038-40.

4. Maithani T, Dey D, Sharma C. Spontaneous cervicofacial subcutaneous emphysema secondary to pneumomediastinum in an otherwise asymptomatic child. Ear Nose Throat J. 2012;91:E9-11.
5. Cremaschini G, Sassi G, Tedoldi S, Corna A, Vaccaro T, et al. An unusual pneumomediastinum case in a child caused by spontaneous bronchial rupture. Minerva Pediatr. 2012;64:243-9.

6. Ojima H, Fukai Y, Soda M, Kuwano H. Asymptomatic spontaneous cervical and mediastinal emphysema. BMJ case reports. 2012;2012.

7. Belotti EA, Rizzi M, Rodoni-Cassis $P$, Ragazzi M, ZanolariCaledrerari $M$, et al. Air within the spinal canal in spontaneous pneumomediastinum. Chest. 2010;137:1197-200.

8. Oertel MF, Korinth $M C$, Reinges $M H$, Krings $T$, Terbeck $S$, et al. Pathogenesis, diagnosis and management of pneumorrhachis. Eur Spine J. 2006;15 Suppl 5:636-43.

9. Tortajada-Girbes M, Moreno-Prat M, Ainsa-Laguna D, Mas S. Spontaneous pneumomediastinum and subcutaneous emphysema as a complication of asthma in children: case report and literature review. Ther Adv Respir Dis. 2016;10:402-9.

10. Carolan PL, Wright SL, Jha V. Spontaneous pneumorrhachis. Pediatr Emerg Care. 2013;29:508-9. 